\title{
$Y$ chromosome loss is associated with age-related male patients with abdominal aortic aneurysms
}

This article was published in the following Dove Press journal:

Clinical Interventions in Aging

\author{
Dianjun Tang ${ }^{1,2, *}$ \\ Yanshuo $\mathrm{Han}^{3, *}$ \\ Yu Lun' \\ Han Jiang' \\ Shijie Xin' \\ Zhiquan Duan' \\ Jian Zhang'
}

'Department of Vascular Surgery, The First Hospital of China Medical University, Key Laboratory of

Pathogenesis, Prevention and Therapeutics of Aortic Aneurysm Liaoning Province, Shenyang, People's Republic of China; ${ }^{2}$ Department of Vascular Surgery, The Second Hospital of Shandong University, Jinan, People's Republic of China; ${ }^{3}$ Department of General Surgery, Shengjing Hospital of China Medical University, Shenyang, People's Republic of China

*These authors contributed equally to this work
Correspondence: Jian Zhang

Department of Vascular Surgery, First Hospital of China Medical University,

Najing Bei Street, Shenyang II000I,

People's Republic of China

Tel $+86(024) 83283280$

Fax $+86(024) 83283288$

Email jianzhang@cmu.edu.cn

\begin{abstract}
Purpose: Abdominal aortic aneurysm (AAA) demonstrates many features of autoimmune diseases. Y chromosome, sex-determining region of the Y chromosome (SRY) gene, androgen receptor $(A R)$ gene, and androgen appear as potential candidates for influence of the male immune function. This study investigated $\mathrm{Y}$ chromosome numbers, $S R Y$ gene, $A R$ gene, and androgen levels in male AAAs. We also investigated the correlation between $\mathrm{Y}$ chromosome loss (LOY) ratio, $S R Y$ expression, androgen levels, and age.

Patients and methods: We investigated LOY by fluorescence in situ hybridization (FISH) in 37 AAAs and compared with 12 patients with abdominal aortic atherosclerotic occlusive disease (AOD) and 91 healthy controls (HC). We investigated $S R Y$ and $A R$ expression at mRNA level by real-time PCR in peripheral T lymphocytes in AAA compared with AOD and $\mathrm{HC}$, and AR protein levels by immunohistochemistry (IHC) in AAA. LOY, SRY expression, androgen levels, and age were examined for correlations using the Spearman's rank correlation coefficient.
\end{abstract}

Results: LOY ratio in peripheral $\mathrm{T}$ lymphocytes was significantly higher in the AAA group compared with the HC $(9.11 \%$ vs $5.56 \%, P<0.001)$ and AOD groups $(9.11 \%$ vs $6.42 \%$, $P=0.029$ ). The SRY mRNA expression in peripheral $\mathrm{T}$ lymphocytes was 4.7 -fold lower expressed in the AAA group than in the $\mathrm{HC}$ group $(P<0.001)$. Free plasma testosterone levels were lower in the AAA group compared with the HC group $(P=0.036)$, whereas sex hormone-binding globulin levels were higher $(P=0.020)$. LOY ratio and expression of $S R Y$ mRNA level increased with age in the AAA group ( $\mathrm{R}=0.402$ and, $\mathrm{R}=0.366$, respectively). A significant correlation between AR mRNA level $(R=0.692)$ and aortic diameter was detected. Simultaneously, in AAA tissue, the rate of LOY increased with age $(\mathrm{R}=0.547)$ and also positively associated with LOY in peripheral blood $\mathrm{T}$ lymphocytes $(\mathrm{R}=0.661)$.

Conclusion: This study identified a prominent $\mathrm{Y}$ chromosome loss in male AAAs, which is correlated to age, lower level of $S R Y$ expression and free testosterone, providing a new clue for the mechanisms of AAA.

Keywords: abdominal aortic aneurysm, age-related, $\mathrm{Y}$ chromosome, sex-determining region of the $\mathrm{Y}$ chromosome (SRY), testosterone

\section{Introduction}

Abdominal aortic aneurysm (AAA) is a major cause of morbidity and mortality in western countries, ${ }^{1,2}$ the incidence and prevalence of which in China have increased significantly during the last two decades. ${ }^{3}$ Despite surgical advances, the recent interest in developing new therapies for treating small asymptomatic, nonoperation-indicated AAA has led to greater efforts to investigate and define its cellular and molecular nature. Increasing evidence suggests that the immune response contributes to the development of aneurysmal diseases, and AAAs demonstrate many features of 
autoimmune diseases, including genetic predisposition, organ specificity, and chronic inflammation. ${ }^{4,5}$ It is well documented that infiltrating $\mathrm{T}$ cells are essentially always present in AAA lesions, and AAA is likely a specific autoimmune T-cell disease. ${ }^{6}$ Besides, a striking gender difference exhibited in AAA patients revealed a male: female ratio of up to $4: 1$, and male sex is one of the strongest risk factors for AAA. ${ }^{7}$ Pathogenetic hypotheses include possible roles for androgen, environmental triggers, and genetic susceptibility.

The genetic influence on AAA initially focused on the relevance of autosomal genes, and possible susceptibility gene(s) have been identified in rare cases of AAAs with familial tendencies. ${ }^{8,9}$ However, most AAAs are sporadic, and no relevant genetic factors have yet been identified in these cases. Sex chromosomes have been recently investigated in terms of loss of mosaicism, reactivation, and haploinsufficiency in numerous autoimmune diseases and cancers, and other diseases demonstrating sexual dimorphism. ${ }^{10-14}$ The $\mathrm{Y}$ chromosome contains many genes related to sex determination, hormone generation, and fertility, but also harbors several $\mathrm{X}$ homologs, which might exert relevant roles in immune function. ${ }^{15}$ The sexdetermining region of the $\mathrm{Y}$ chromosome (SRY) gene includes a high-mobility group domain, a conserved motif present in many DNA-binding proteins, which could be involved in the regulation of multiple functions such as postnatal steroidogenesis and spermatogenesis. ${ }^{16}$

A recent large population-based study of Australian men showed that patients with AAA had lower free and total testosterone levels than men without AAA. ${ }^{17}$ Furthermore, levels of free testosterone were inversely correlated with AAA, suggesting that decreased levels of testosterone were associated with aortic dilation. These results challenge previous ideas that androgens play a pathogenetic role in vascular physiology and pathophysiology and promote the development of AAA, ${ }^{17,18}$ indicating the need for more studies examining the role of the male sex chromosome in AAA.

In this study, we investigated $\mathrm{Y}$ chromosome numbers in $\mathrm{T}$ lymphocytes and aneurysmal tissue in men with AAA. We also detected mRNA expression of $S R Y$ and androgen levels anf investigated the correlation between SRY, AR expression, and age.

\section{Materials and methods}

\section{AAA population selection}

Between January 2009 and December 2018, a total of 364 AAA patients registered in China Medical University aneurysm Biobank (CMUaB) and China Medical University aneurysm blood Biobank (CMUabB) were selected to this study, which were obtained from the Department of Vascular Surgery of the First Hospital of China Medical University (CMU) and Department of General Surgery of Shengjing Hospital of CMU. The AAA tissue specimen, peripheral blood samples, and corresponding clinical data were collected from these patients consecutively, after aneurymal open surgery (OSR). Simultaneously, peripheral blood samples and related clinical data were extracted within these patients consecutively, after endovascular repair (EVAR).

Inclusion criteria for AAA patients in this study were: 1) male patients with an infrarenal abdominal aorta diameter above $30 \mathrm{~mm}$ or larger than 1.5-2 times the diameter of the abdominal aorta in their normal segment diagnosed by three-dimensional computed tomography angiography (3D-CTA) ${ }^{19}$ 2) availability of corresponding patient history and clinical data, including history of ruptured, history of coronary and peripheral artery disease, medication history, and the presence of risk factors of atherosclerosis, such as smoking habits, hypertension, diabetes mellitus, or hyperlipidemia. Exclusive criterion: male AAA patients with EhlersDanlos syndrome, Marfan syndrome, and other known vascular disorders were excluded. None of the patients had any evidence or medical history of other autoimmune diseases.

\section{AAA tissue specimen}

126 patients from $\mathrm{CMUaB}$ were examined by an experienced vascular surgeon within 2 days before and after the OSR. Until December 2018, nine patients not willingly and openly reveal their inpatients of information via publication, whether their clinical data, aneurymal tissue, or blood sample. Finally, aneurysm specimens from 96 male patients were eligible for further analyses. Here, AAA tissue specimen $(n=17)$ and corresponding peripheral blood samples $(n=17)$ were obtained who underwent OSR. All samples were harvested at the most dilated place of aortaventralis, by which tissues in vitro were washed in PBS (Boster, Wuhan, China), opened transversely, and fixed in 4\% paraformaldehyde (Beijing Chemical Works, Beijing, China) for 24 hrs. The samples were then embedded in paraffin and sectioned transversely at 2-3 $\mu \mathrm{m}$ continuously to make parallel sections. Immunofluorescence was stained by anti-CD3 monoclonal antibody (BD Biosciences, San José, CA, USA) to 
identify $\mathrm{T}$ lymphocytes on one section for cell type analysis and localization and the other was prepared for fluorescence in situ hybridization (FISH).

\section{AAA peripheral blood samples}

A total of 338 patients from CMUabB were examined by an experienced vascular surgeon within 2 days before and after the EVAR. Until December 2018, 29 patients discarded reveal their inpatients' information, eg, clinical data, blood laboratory results, and blood sample. Finally, aneurysm specimens from 254 male AAA patients were eligible for further analyses. The androgen level in serum sample, total RNA extraction and chromosome preparations in peripheral blood mononuclear cell (PBMC) we need to performed, both serum and PMBC samples were obtained successfully in 20 male AAA patients who underwent EVAR shown in Figure 1. Blood was obtained preoperatively from patients and controls between 5 and 6 o'clock in the early morning in $10-\mathrm{mL}$ anticoagulant tubes, with three tubes per sample.

\section{Normal control population selection}

The normal control group comprised age-matched healthy control males (HCs) $(\mathrm{n}=91,50-84$ years old, aorta diameter $16.9-25.8 \mathrm{~mm}$ ), selected from a healthy population who received annual regular physical examinations. HCs had a relatively healthy peripheral vascular system determined by ultrasonography, and there was no evidence or medical history of aneurysm, abdominal aortic atherosclerotic occlusive disease (AOD), or other vascular disorders. Other exclusion criteria were cancer, infection, and any other immune-mediated disease. We collected clinical data, blood laboratory results, and blood samples from the $\mathrm{HC}$ group as controls.

\section{AOD population selection}

Because AAA patients also had prominent atherosclerosis, we selected a second control group of age-matched men with infrarenal AOD from our hospital $(\mathrm{n}=12,49-79$ years, aorta diameter $14.8-25.6 \mathrm{~mm}$ ), with no medical history of aneurysmal disease, other vascular disorders, connective tissue disorders, or known autoimmune diseases. AOD was diagnosed by enhanced CT scanning or 3D-CTA. This group was used to control for any potential involvement of atherosclerosis in the possible autoimmune mechanisms, especially in early lesions. We collected clinical data, blood laboratory results, and blood samples from the AOD group as another control.

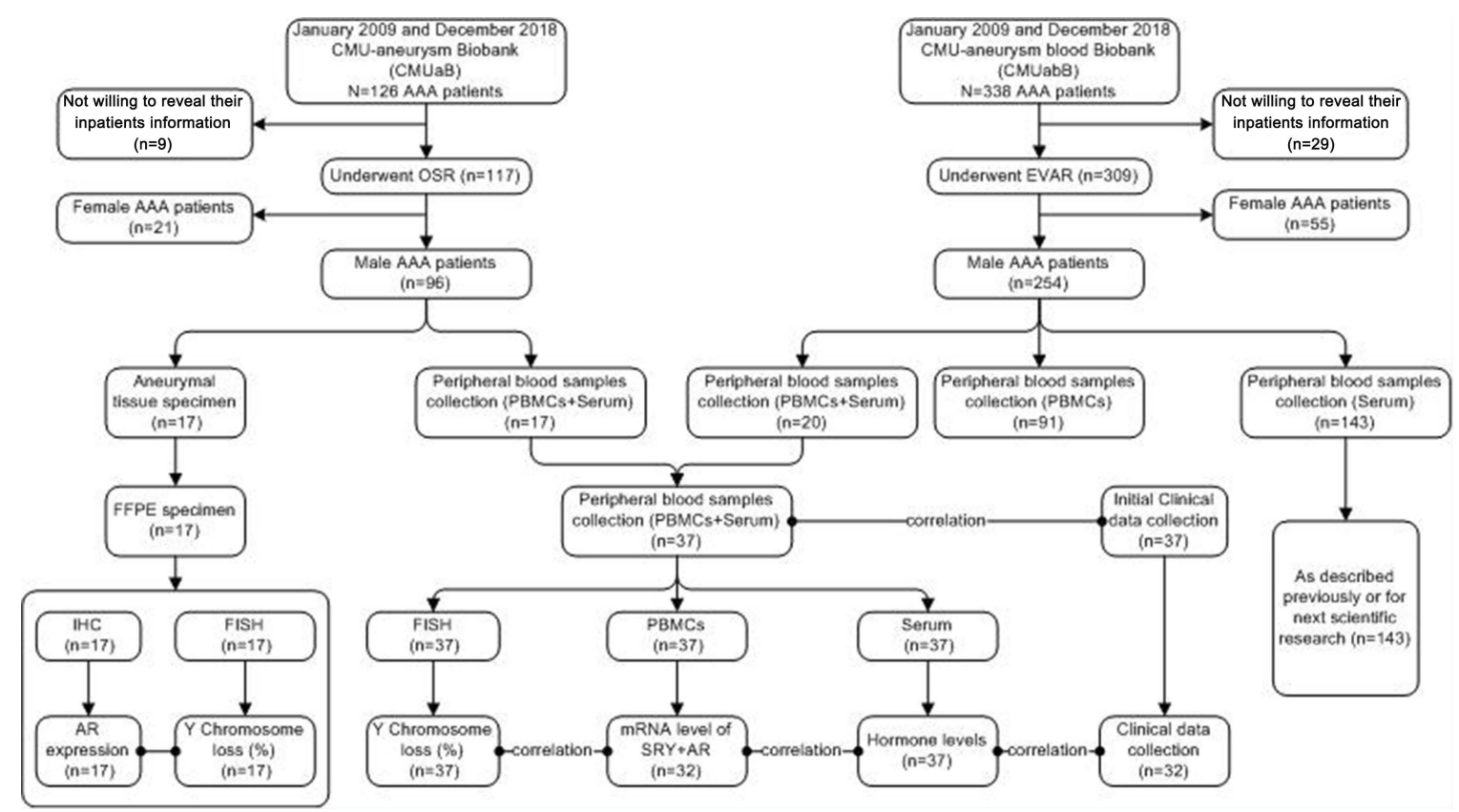

Figure I Flowchart of AAA patient selection and biopsy tissue from China Medical University Aneurysm Biobank (CMU-aB) or peripheral blood sample recovered from China Medical University Aneurysm blood Biobank (CMU-abB).

Abbreviations: AAA, abdominal aortic aneurysm; FFPE, formalin-fixed paraffin-embedded; EVAR, endovascular repair; OSR, open surgical repair; PBMCs, peripheral blood mononuclear cells; FISH, fluorescence in situ hybridization; IHC, immunohistochemistry; SRY, sex-determining region of the $Y$ chromosome; AR, androgen receptor. 


\section{Ethics approval and consent to participate}

Written informed consent was obtained from AAA patients, AOD patients, and controls in the study, before tissue and blood sampling. This study was performed according to the Guidelines of the World Medical Association Declaration of Helsinki and was approved by the local ethics committee of the China Medical University. The selection process of the corresponding patients is summarized in Figure 1.

\section{Peripheral blood mononuclear cell (PBMC) extraction and T-cell preparation} PBMCs were extracted by Ficoll-sodium diatrizoate (Ficoll-Hypaque, Haoyang TBD, Co, Tianjin, China) density-gradient centrifugation. After several washing steps with PBS, PBMCs were allowed to adhere to the plastic for $2 \mathrm{hrs}$ at $37^{\circ} \mathrm{C}$ to deplete monocytes. Floating cells were collected and expression of CD3 in fresh peripheral blood lymphocytes was evaluated by flow cytometry (FACSCalibur; BD Biosciences) using PerCP-conjugated anti-CD3 monoclonal antibody (BD Biosciences) to identify the population of $\mathrm{T}$ lymphocytes. Each sample contained $>90 \%$ CD3 $+\mathrm{T}$ lymphocytes at the time of assessment (Figure 2).

\section{Serum preparation}

Serum was prepared after centrifuge of blood and stored at $-80^{\circ} \mathrm{C}$ until assayed. Total serum levels of testosterone, dehydroepiandrosterone (DHS), and sex hormone-binding globulin (SHBG) were determined by chemiluminescent immunoassays using Immulite 2000 total testosterone, Immulite 2000 DHEA-SO4, and Immulite 2000 SHBG assays (Siemens Healthcare Diagnostics Products Limited, Llanberis, UK) on an Immulite 2000 analyzer (Siemens
Healthcare Diagnostics, Flanders, USA). Free testosterone was determined by chemiluminescent immunoassay using free testosterone in vitro diagnostic kits (Snibe, Shenzhen, China) on a Maglumi 4000 analyzer (Snibe). The working ranges for total testosterone, DHS, SHBG, and free testosterone were $0.7-55 \mathrm{nmol} / \mathrm{L}, 0.41-27 \mu \mathrm{mol} / \mathrm{L}, \leq 180 \mathrm{nmol} / \mathrm{L}$, and $0.50-150.0 \mathrm{pg} / \mathrm{mL}$, respectively. The sensitivities were $0.5 \mathrm{nmol} / \mathrm{L}, 0.08 \mu \mathrm{mol} / \mathrm{L}, 0.02 \mathrm{nmol} / \mathrm{L}$, and $0.5 \mathrm{pg} / \mathrm{mL}$, respectively, and the reference values were $6.27-$ $26.28 \mu \mathrm{nmol} / \mathrm{L}, 2.17-15.20 \mu \mathrm{mol} / \mathrm{L}, 13.00-71.00 \mathrm{nmol} / \mathrm{L}$, and 55.05-183.50 pmol/L, respectively, according to the Institute of Endocrinology, the First Affiliated Hospital of China Medical University.

\section{Chromosome preparations and FISH analysis}

$\mathrm{T}$ lymphocytes were separated from peripheral blood (AAA, n=37; AOD, n=12; HC, n=91) and prepared as follows. Cytology Pepsin Solution (Zytovision, Bremen, Germany) was applied to the cytology specimens and incubated for 5 mins at $37^{\circ} \mathrm{C}$ in a humidity chamber. The slides were then incubated in $1 \%$ wash buffer Tris- $\mathrm{HCl}$ buffer solution (TBS) 1\% formaldehyde solution, and again in $1 \times$ wash buffer TBS (Zytovision) for 5 mins each, dehydrated in $70 \%, 90 \%$, and $100 \%$ ethanols for $1 \mathrm{~min}$ each, and then air dried. Ten microliters of CENX/Yq12 dual-color probe (Zytovision) was pipetted onto each individual sample, covered with a coverslip (22 $\mathrm{mm} \times 22 \mathrm{~mm})$, and sealed with rubber cement (Zytovision). The slides were denatured at $72 \pm 1^{\circ} \mathrm{C}$ for 2 mins on a hot plate, transferred to a humidity chamber (Abbott, Chicago, USA), and hybridized overnight at $37^{\circ} \mathrm{C}$. The cement and coverslip were removed the following day using Cytology Stringency Wash Buffer SSC (Zytovision) for 2 minss at $72 \pm 1^{\circ} \mathrm{C}$ for
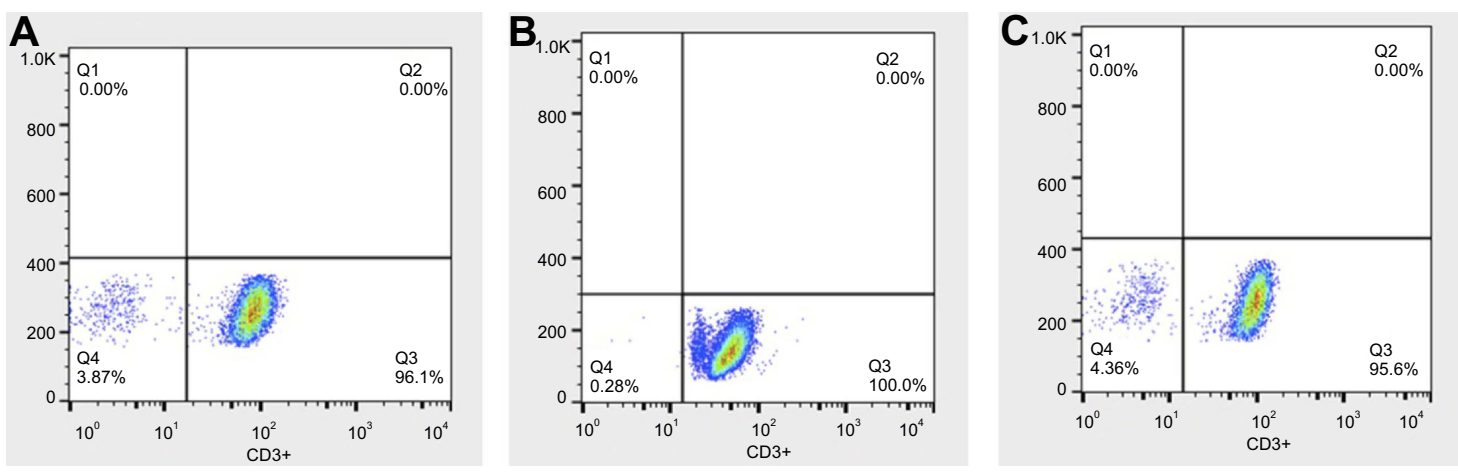

Figure 2 Purity of isolated T cells as determined by flow cytometry in blood samples of AAA (A), AOD (B), and HC (C). Abbreviations: AOD, aortic atherosclerotic occlusive disease; HC, healthy controls; AAA, abdominal aortic aneurysm. 
$1 \mathrm{~min}$ at room temperature. Thirty microliters of DAPI (Zytovision) was then pipetted onto the slides, covered with a coverslip ( $24 \mathrm{~mm} \times 60 \mathrm{~mm}$ ), avoiding trapped bubbles, and incubated in the dark for 15 mins.

$\mathrm{T}$ lymphocytes of AAA tissue specimen $(\mathrm{n}=17)$ were prepared as follows. Cytology Pepsin Solution (Zytovision) was applied to the cytology specimens and incubated for 10 mins at $37^{\circ} \mathrm{C}$ in a humidity chamber, followed by incubation in $1 \times$ wash buffer TBS, $1 \%$ formaldehyde solution, and $1 \times$ wash buffer TBS (Zytovision) for 5 mins each; dehydrated in $70 \%, 90 \%$, and $100 \%$ ethanols for $1 \mathrm{~min}$ each, and then air dried. Ten microliters of CENX/Yq12 dual-color probe (Zytovision) was pipetted onto each individual sample, covered with a coverslip (22 $\mathrm{mm} \times 22 \mathrm{~mm})$, and sealed with rubber cement (Zytovision). The slides were denatured at $83 \pm 1^{\circ} \mathrm{C}$ for 2 min on a hot plate, transferred to a humidity chamber (Abbott), and hybridized overnight at $37^{\circ} \mathrm{C}$. The rubber cement and coverslip were removed carefully the following day using Cytology Stringency Wash Buffer SSC (Zytovision) for $2 \mathrm{mins}$ at $72 \pm 1^{\circ} \mathrm{C}$ for $1 \mathrm{~min}$ at room temperature. Thirty microliters of DAPI (Zytovision) was then pipetted onto the slides, covered with a coverslip $(24 \mathrm{~mm} \times 60 \mathrm{~mm})$ avoiding trapped bubbles, and incubated in the dark for 15 mins.

All samples were analyzed under an Olympus Bx51 microscope equipped with DAPI and Fluorescein isothiocyanate-Tetramethyl isothiocyanate (FITC-TRITC) epifluorescence optics and a digital camera by two independent observers, who were blinded to the patient's characteristics. Hybridization signals were captured using a CytoVision system (Leica Biosystems, Nussloch, Germany). At least 500 nuclei were scored for each sample, and the $\mathrm{Y}$ chromosome loss rate was expressed as a percentage $(\%)$ of the total number of nuclei counted.

\section{RNA extraction and real-time PCR}

To study SRY and androgen receptor (AR), total RNA was isolated from peripheral $\mathrm{T}$ lymphocytes (AAA, $\mathrm{n}=32$; AOD, $\mathrm{n}=12 ; \mathrm{HC}, \mathrm{n}=54$ ) using Trizol reagent (Invitrogen, Carlsbad, CA, USA), according to the manufacturer's protocol. RNA quality and quantity were assessed by NanoDrop ND-1000 (Thermo Fisher Scientific, Waltham, MA, USA) analysis of 260/280 ratios. High-quality RNA samples were obtained with an A260/A280 ratio >1.8. RNA was treated with DNase I (Takara, Dalian, China) before reverse transcription to eliminate contaminating genomic DNA. Total RNA was reverse transcribed with reverse transcriptase (PrimeScript RT Reagent Kit; Takara) and oligo-dT primer, according to the manufacturer's instructions. Real-time fluorescent quantitative PCR was performed using SYBR-green I Premix Ex Taq (Takara) using the Thermo 9700 Real-Time PCR System (Thermo Fisher), following the manufacturer's instructions, with $\mathrm{ddH} 2 \mathrm{O}$ as a negative control. The primers for glyceraldehyde 3-phosphate dehydrogenase (GAPDH) were 5'-C CACCCATGGCAAATTCCCATGGCA-3' (sense) and 5'TCTAGACGGCAGGTCAGGTCCACC-3' (anti-sense), which was used as an endogenous control. The primers for SRY were 5'-CGCATTCATCGTGTGGTCT-3' (sense) and 5'-GCCATTTTTCGGCTTCAGTA-3' (anti-sense), primers for AR were 5'-GCAGGAAGCAGTATCCGAAG-3' (sense) and 5'-TTGGCGTTGTCAGAAATGG-3' (antisense). Thermal cycle parameters were: $95^{\circ} \mathrm{C}$ for $30 \mathrm{~s}$ for 1 cycle, then $95^{\circ} \mathrm{C}$ for $5 \mathrm{~s}$, and $60^{\circ} \mathrm{C}$ for $30 \mathrm{~s}$ for 40 cycles. All PCR assays were carried out in duplicate, and data were analyzed with the Thermo 9700 Real-Time PCR System (Thermo Fisher) using the comparative threshold cycle $\left(2^{-\Delta \Delta \mathrm{CT}}\right)$ method.

\section{Histological, immunohistochemistry (IHC), and immunofluorescence analysis}

The AAA fragments were prepared as aforesaid and samples were embedded in paraffin to obtain transverse sections. Serial sections were cut at $2-3 \mu \mathrm{m}$ and prepared for H\&E, immunochemical, and immunofluorescence staining.

Histological evaluation: The quality of each slide was assessed twice independently as follows: no staining (-), weak positive staining $( \pm)$, scattered positive staining $(+)$, majority positive staining $(++)$, and strong overall positive staining $(+++)$. These score analyses were performed for all cells within the vessel wall and for all specimens. In addition, for interrelated quality evaluation between the abovementioned quality evaluation following scoring was used: $+/++$ and $++/+++$.

IHC analysis: The sections were treated with $3 \%$ hydrogen peroxide/methanol (Mai Xin_Bio, Fuzhou, China), followed by incubating with rabbit monoclonal antibody against AR (ab133273,1:100; Abcam, Cambridge, UK) or mouse monoclonal antibody against CD3 (sc-20047, 1:500; Santa Cruz Biotechnology, Shanghai, China) in $2 \%$ BSA PBS overnight at $4^{\circ} \mathrm{C}$. After being washed with PBS, the sections were incubated with anti-rabbit/mouse IgG-HRP antibody (Boster) for 0.5 hrs at $37^{\circ} \mathrm{C}$. Finally, 3,3'-diaminobenzidine (DAB) (Mai 
Xin_Bio) was used as a chromogen for 10 mins until the brown yellow color appeared. Four visual fields were randomly selected on each slide. Light microscopic results were graded semiquantitatively from 0 (to the corresponding no staining change) to +3 (to the corresponding strong staining change: +++ ). This histopathological grading was performed for endothelial cells, inflammatory infiltrate, and macrophages in the AAA tissue samples.

Immunofluorescence analysis: The sections were treated with 3\% hydrogen peroxide/methanol (Mai Xin_Bio), followed by incubating with rabbit monoclonal antibody against AR (ab133273,1:100; Abcam) or mouse monoclonal antibody against CD3 (sc-20047, 1:500; Santa Cruz Biotechnology) in $2 \% \mathrm{BSA}$ PBS overnight at $4^{\circ} \mathrm{C}$. After being washed with PBS, the sections were incubated with FITC-labelled secondary anti-rabbit/mouse IgG-HRP antibody (Boster) for $0.5 \mathrm{hrs}$ at room temperature in $0.5 \% \mathrm{BSA} /$ PBS. Coverslips were mounted in Prolong Gold with (DAPI) (Zytovision), then pipetted onto the slides, covered with a coverslip ( $24 \mathrm{~mm} \times 60 \mathrm{~mm}$ ), avoiding trapped bubbles, and incubated in the dark for 15 mins. All samples were analyzed under an Olympus Bx51 microscope equipped with DAPI and FITC-TRITC epifluorescence optics and a digital camera.

\section{Statistical analysis}

Data were tested by the Shapiro-Wilk's test and followed a normal distribution. Independent $t$-test was used for comparisons of normally distributed data and MannWhitney $U$ test for not normally distributed data. Pearson's Chi-square test and Fischer's exact test were used for normally and not normally distributed categorical variables, respectively. For correlational analyses, correlations between continuous variables were analyzed first through Pearson's correlation coefficient for normally distributed values or through Spearman's rank correlation coefficient for nonparametric samples. The correlations between plasma TES, androstenedione (AND), SHBG, DHS, free plasma testosterone (F-TES), diameter, LOY $\%$, and mRNA of SRY were analyzed through partial correlation analysis adjusted by age. Statistical comparisons were performed using SPSS 20.0 (IBM, Chicago, IL, USA). Statistical significance was defined as $P<0.05$.

\section{Results}

\section{Characterization of AAA and AOD}

\section{patients analysis}

The experimental study group included 37 male patients (17 underwent OSR, 20 underwent EVAR) of infrarenal AAA. The youngest AAA subject was 49 years and the oldest 81 years old. Regarding the comparison of the study groups (AAA group vs AOD group vs HC group) as shown in Table 1, no significant differences were observed in age, hypertension, and other indices (all $P$-value $>0.05$ ). As respected, the mean maximum diameter of AAA was

Table I Clinical features in patients with AAA, AOD, and healthy controls

\begin{tabular}{|c|c|c|c|c|c|c|}
\hline Parameter & $\begin{array}{l}\text { AAA } \\
\text { group } \\
(n=37)\end{array}$ & $\begin{array}{l}\text { AOD } \\
\text { group } \\
(n=12)\end{array}$ & $\begin{array}{l}\text { Healthy con- } \\
\text { trols }(n=91)\end{array}$ & $\begin{array}{l}\text { AAA tissue speci- } \\
\text { men }(n=17 \text { in } 37)\end{array}$ & $\begin{array}{l}P \text {-value } \\
\text { AAA vs } \\
\text { AOD }\end{array}$ & $\begin{array}{l}\text { P-value } \\
\text { AAA vs } \\
\text { HC }\end{array}$ \\
\hline *Age (years) & $64.53 \pm 7.30$ & $61.25 \pm 10.40$ & $63.55 \pm 8.21$ & $64.54 \pm 8.01$ & 0.20 & 0.38 \\
\hline *Smoking history & $12(40 \%)$ & $5(41.6 \%)$ & $26(37.14 \%)$ & $6(35.3 \%)$ & 0.92 & 0.79 \\
\hline smokers (pack-years) & $34.60 \pm 22.58$ & $37.00 \pm 12.04$ & $32.08 \pm 19.46$ & $34.25 \pm 8.74$ & 0.82 & 0.68 \\
\hline Hypertension history & $14(46.67 \%)$ & $2(16.7 \%)$ & $28(40.00 \%)$ & $8(47.1 \%)$ & 0.09 & 0.53 \\
\hline Diabetes history & $4(13.33 \%)$ & I (8.33\%) & II (15.7I\%) & $2(11.76 \%)$ & 0.65 & 0.76 \\
\hline Coronary disease & $6(20.00 \%)$ & $2(16.67 \%)$ & $12(17.14 \%)$ & $4(23.52 \%)$ & 0.80 & 0.73 \\
\hline *WBC count $\left(\times 10^{9} / \mathrm{L}\right)$ & $6.67 \pm 2.86$ & $7.16 \pm 2.05$ & $6.7 I \pm 1.57$ & $6.70 \pm 2.99$ & 0.47 & 0.17 \\
\hline *Lymph count $\left(\times 10^{9} / \mathrm{L}\right)$ & $\mathrm{I} .8 \mathrm{I} \pm 0.77$ & $1.90 \pm 0.82$ & $1.79 \pm 0.70$ & $1.83 \pm 0.74$ & 0.39 & 0.53 \\
\hline *Triglycerides (mmol/L) & $1.65 \pm 0.73$ & $1.49 \pm 0.76$ & $1.55 \pm 0.70$ & $1.67 \pm 0.65$ & 0.43 & 0.48 \\
\hline$* \mathrm{TC}(\mathrm{mmol} / \mathrm{L})$ & $4.84 \pm 0.76$ & $4.80 \pm 0.81$ & $4.78 \pm 0.87$ & $4.86 \pm 0.83$ & 0.64 & 0.62 \\
\hline *HDL-C (mmol/L) & $0.99 \pm 0.32$ & $0.95 \pm 0.34$ & $1.06 \pm 0.31$ & $1.01 \pm 0.30$ & 0.89 & 0.22 \\
\hline$* \mathrm{LDL}-\mathrm{C}(\mathrm{mmol} / \mathrm{L})$ & $3.46 \pm 0.73$ & $3.20 \pm 0.70$ & $3.29 \pm 0.79$ & $3.40 \pm 0.69$ & 0.18 & 0.57 \\
\hline $\begin{array}{l}\text { *Mean maximum diameter } \\
(\mathrm{mm})\end{array}$ & $56.63 \pm 15.28$ & $|8.96 \pm 2.7|$ & $18.98 \pm 1.60$ & $56.83 \pm 15.47$ & $<0.0001$ & $<0.0001$ \\
\hline
\end{tabular}

Note: AAA group, abdominal aortic aneurysm patients sampled for T cells; AAA tissue specimen; abdominal aortic aneurysm patients with aneurysm samples. *Continuous data are presented as mean \pm SD.

Abbreviations: AOD, aortic atherosclerotic occlusive disease; HC, healthy controls; WBC, white blood cell count; TC, total cholesterol; HDL-C, high-density lipoprotein cholesterol; LDL-C, low-density lipoprotein cholesterol. 
56.6 $\pm 15.3 \mathrm{~mm}$ which was significantly higher than AOD and $\mathrm{HC}$ group.

As reported, tobacco smoking was a possible risk factor for $\mathrm{Y}$ chromosome loss. ${ }^{20}$ Therefore, a corresponding number of smoking individuals have been selected in control groups to eliminate the possible interference. The individuals were selected to ensure that there was no significant difference in the rate of smokers and smoking index (pack-years) in AAA, AOD, and HC groups (also in Table 1). Smoker was defined in this study as continuous smoking for more than half a year and at least 10 cigarettes per day (WHO1997).

\section{Incidence of LOY and SRY expression in AAA peripheral $T$ lymphocytes}

A total of 70,000 interphase nuclei from peripheral $\mathrm{T}$ lymphocyte of the 37 male AAA patients, 12 male AOD patients, and 91 male donors were analyzed by in situ hybridization for $\mathrm{X}$ and $\mathrm{Y}$ hypoploidy, respectively (Figure 3). Y chromosome loss in peripheral T lymphocytes detected by FISH was significantly higher in the AAA group compared with the $\mathrm{HC} \quad(9.11 \pm 3.96 \%$ vs 5.56 $\pm 3.50 \%, P<0.001)$ and AOD groups $(9.11 \pm 3.96 \%$ vs 6.42 $\pm 1.93 \%, P=0.029)$. There was no significant difference in $\mathrm{Y}$ chromosome loss between AOD groups and HC groups $(P=0.253)$ (Figure 4A). Furthermore, we investigate the correlation between the rate of $\mathrm{Y}$ chromosome loss correlate and other baseline factors in AAAs. After logistic regression analysis, there were no significant correlations between LOY and comorbidity such as hypertension, diabetes mellitus, coronary artery disease, and smoking history in patients with AAA (Table S1).

The SRY mRNA expression in peripheral $\mathrm{T}$ lymphocytes was 4.7-fold lower expressed in the AAA group than in the HC group $(P<0.001)$. Moreover, $S R Y$ mRNA expression in peripheral $\mathrm{T}$ lymphocytes was significantly lower in AOD group than in HC group (0.19 \pm 0.12 vs $3.94 \pm 2.68, P<0.001)$, but there was no significant difference between the AAA and AOD group $(P=0.328)$ in Figure 4B.

\section{Plasma sex hormone level and androgen receptor level in AAA patients and controls}

F-TES levels were lower in the AAA group compared with the HC group $(P=0.036)$, whereas SHBG levels were higher $(P=0.020)$. There was no significant difference between the
AAA and HC groups in terms of total testosterone (TEST), DHS, and AND level (Table 2). However, there was no significant difference in the expression of androgen receptor $(A R)$ mRNA level between the AAA group and $\mathrm{HC}$ group $(P=0.083)$, AOD group $(P=0.140)$ in Figure $4 \mathrm{C}$.

\section{Correlations between peripheral LOY and age-related AAA or sex hormone level}

In Table 3, peripheral LOY ratio and expression of SRY mRNA level were examined for correlations using the Spearman's rank correlation coefficient due to the heterogeneous distribution of the experimental data. As respected, the result demonstrated that peripheral LOY ratio was positive significantly correlated with expression of $S R Y$ mRNA level $(\mathrm{R}=0.709, P<0.001)$ adjusted by age. Second, we analyzed the rate of LOY in peripheral $\mathrm{T}$ lymphocytes in relation to continuous age. $\mathrm{Y}$ chromosome loss and expression of $S R Y$ mRNA level increased with age in the AAA group $(\mathrm{R}=0.402$, $P=0.014$ and $\mathrm{R}=0.366, P=0.039 \mathrm{~S}$, respectively). In addition, plasma SHBG level correlated significantly with SRY mRNA level $(\mathrm{R}=0.433, P=0.039)$ and continuous age in AAA patients $(\mathrm{R}=0.456, P=0.007)$. A significant correlation between $A R$ mRNA level $(\mathrm{R}=0.692$, $P<0.001)$ and aortic diameter was detected adjusted by age.

\section{Incidence of LOY and correlations within AR protein level in AAA tissue}

To assess the extension of the individual histopathological features in AAA wall $(n=17)$, a semiquantitative histological characterization of all AAA tissue samples was performed (Table 4). There was no significant difference in $\mathrm{Y}$ chromosome loss between AAA peripheral blood $\mathrm{T}$ lymphocytes and AAA tissues $(9.14 \pm 3.93 \%$ for peripheral $\mathrm{T}$ lymphocytes vs $8.08 \pm 2.42 \%$ for AAA tissue, $P=0.460)$. Regarding the AR protein level, using IHC and immunofluorescence, inflammation cells were strongly positive for AR expression, particularly in T lymphocytes (Figure 5). Furthermore, the semiquantitative histological characterization and the results of LOY ratio were analyzed again by calculating correlation coefficient in order to explore any relationships between aneurymal LOY ratio and AR protein level within AAA tissue. There is no significant correlation between LOY ratio and AR protein level $(R=0.052$, 

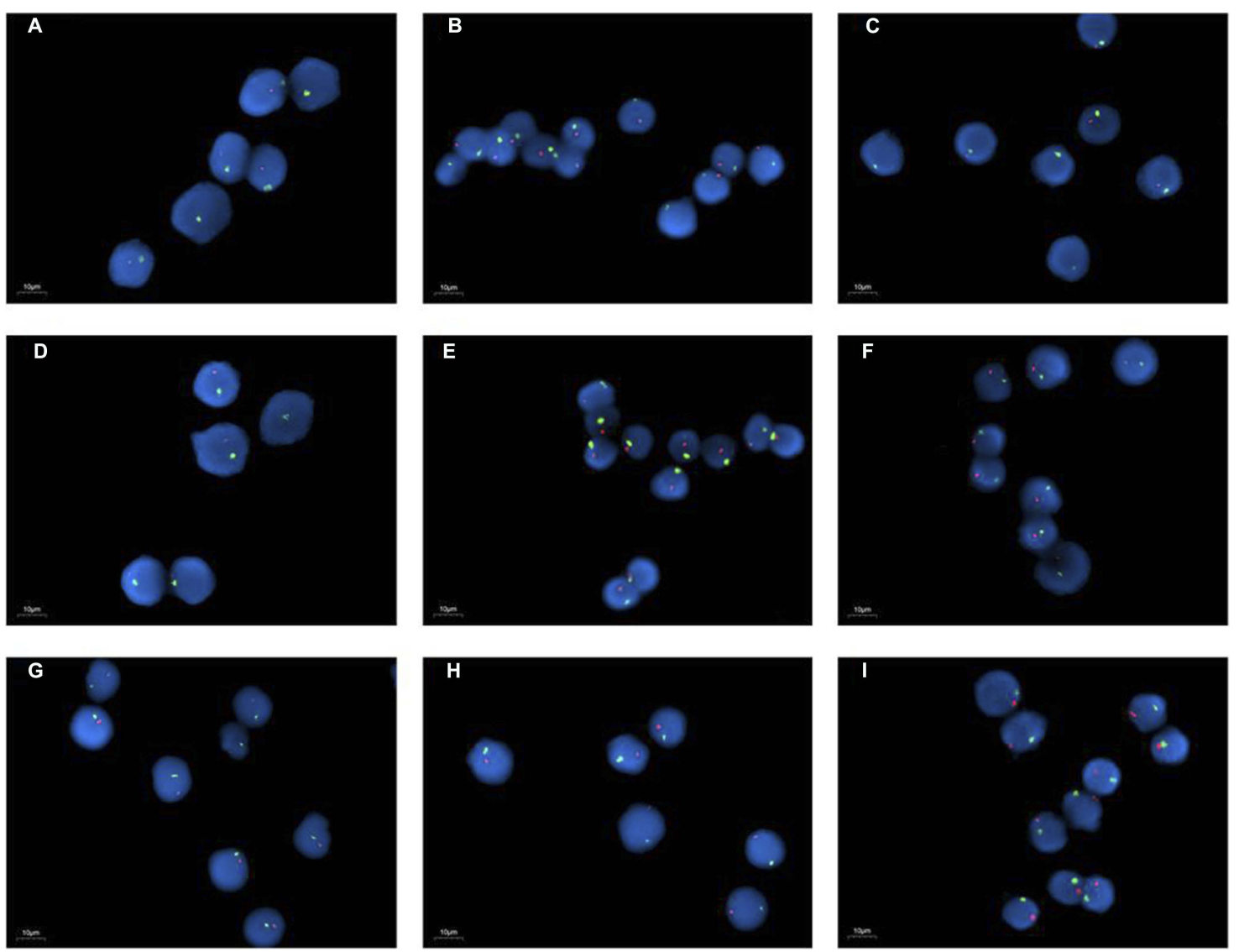

Figure 3 FISH image of $X / Y$ chromosome in peripheral blood T lymphocytes from AAA group (A-C), AOD group (D-F), and HC group $(\mathbf{G}-\mathbf{I})$ individuals $(\times I, 000)$. The $X$ chromosome probe was green labeled and $Y$ chromosome probe was pink labeled. $Y$ chromosome loss can be detected by this image.

Abbreviations: AOD, aortic atherosclerotic occlusive disease; HC, healthy controls; AAA, abdominal aortic aneurysm.
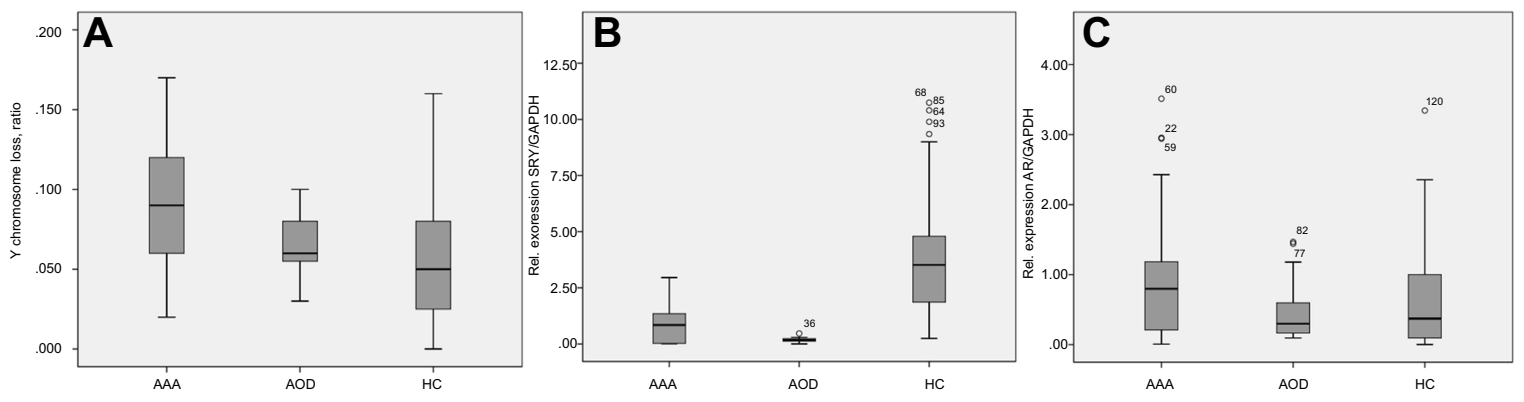

Figure 4 Y chromosome loss ratio (A), mRNA level of SRY (B), and mRNA level of AR (C) in peripheral T cells in AAA, AOD, and HC groups. Note, AAA ( $n=37), A O D(n=12)$, and $\mathrm{HC}(\mathrm{n}=9 \mathrm{I})$ groups. Shapiro-Wilk's test for three groups achieved $P$-value of $0.418,0.82 \mathrm{I}$, and $<0.00$ I, respectively. Thus, the sample was not normal distributed and Mann-Whitney $U$ test was used for the HC group compared with AAA and AOD groups. Relative to AOD and HC groups, AAA group showed a significant increase of $Y$ chromosome loss; (B) AAA $(n=32), A O D(n=12)$ and HC $(n=54)$ groups. Shapiro-Wilk's test for three groups achieved $P$-value of $0.001,0.465$, and $<0.001$, respectively. Thus, the sample was not normal distributed and Mann-Whitney $U$ test was used for the individual comparison group. Compared with HC group, AAA and AOD groups showed a significant decrease of SRY mRNA expression; (C) AAA ( $n=32)$, AOD $(n=12)$, and HC $(n=54)$ groups. Shapiro-Wilk's test for three groups achieved $P$-value of $<0.001,0.001$, and $<0.001$, respectively. Thus, the sample was not normally distributed and Mann-Whitney $\mathrm{U}$ test was used for individual comparison group.

Abbreviations: AOD, aortic atherosclerotic occlusive disease; HC, healthy controls; AAA, abdominal aortic aneurysm; AR, androgen receptor; SRY, sex-determining region of the $Y$ chromosome.

$P=0.844)$. Interestingly, in AAA tissue, the rate of LOY increased with age $(\mathrm{R}=0.547, P=0.023)$ and also positively associated with LOY in peripheral blood T lymphocytes $(\mathrm{R}=0.661, P=0.004)$ (Table 5).

\section{Discussion}

The results of the present study provide the first evidence for an association between $\mathrm{Y}$ chromosome loss in T lymphocytes and AAA in male patients. Previous studies demonstrated an 
Table 2 Plasma sex hormone level in AAA patients and controls

\begin{tabular}{|l|l|l|l|}
\hline Parameter & AAA $(\mathbf{n = 3 7})$ & HC $(\mathbf{n = 9}$ I) & P-value \\
\hline F-TES, pmol/L & $34.60 \pm 26.1 \mathrm{I}$ & $55.49 \pm 24.6 \mathrm{I}$ & 0.036 \\
TEST, nmol/L & $20.60 \pm 9.1 \mathrm{I}$ & $24.94 \pm 8.32$ & 0.192 \\
AND, nmol/L & $5.77 \pm 2.34$ & $5.65 \pm 1.56$ & 0.460 \\
DHS, umol/L & $1.90 \pm 1.56$ & $2.37 \pm 1.50$ & 0.421 \\
SHBG, nmol/L & $33.97 \pm 11.31$ & $21.07 \pm 14.48$ & 0.020 \\
\hline
\end{tabular}

Abbreviations: AAA, abdominal aortic aneurysm; $\mathrm{HC}$, healthy control; TEST, total testosterone; AND, androstenedione; SHBG, sex hormone-binding globulin; DHS, dehydroepiandrosterone; F-TES, free testosterone.

increased incidence of $\mathrm{X}$ monosomy in $\mathrm{PBMC}$ of female patients, ${ }^{11,21}$ and $\mathrm{Y}$ chromosome loss in PBMC was investigated in male patients with autoimmune thyroiditis and primary biliary cirrhosis. ${ }^{15,22}$ Sex chromosome loss is not an exclusively female phenomenon, but it is also associated with disease in the male population. Y chromosome appears as a potential candidate for influence of the immune function in men. $\mathrm{Y}$ chromosome loss has been shown to increase with age, ${ }^{23,24}$ but our findings indicated that the degree of $\mathrm{Y}$ chromosome loss in AAA patients exceeded that in HCs, similar to the situation for X chromosome loss in female primary biliary cirrhosis patient populations. ${ }^{11}$

The reasons for $\mathrm{Y}$ chromosome loss remain unknown, though the rate of cellular turnover and a potential increase

Table 3 Partial correlation analysis of the peripheral T lymphocytes LOY ratio, mRNA expression of SRY and AR, plasma sex hormone level within AAA using partial correlation coefficient

\begin{tabular}{|c|c|c|c|c|c|c|c|c|c|c|}
\hline & & $\begin{array}{l}\text { Plasma } \\
\text { TEST }\end{array}$ & $\begin{array}{l}\text { Plasma } \\
\text { AND }\end{array}$ & $\begin{array}{l}\text { Plasma } \\
\text { DHS }\end{array}$ & $\begin{array}{l}\text { Plasma } \\
\text { F-TES }\end{array}$ & $\begin{array}{l}\text { Plasma } \\
\text { SHBG }\end{array}$ & Diameter & $\begin{array}{l}\text { LOY } \\
\%\end{array}$ & $\begin{array}{l}\text { mRNA- } \\
\text { SRY }\end{array}$ & $\begin{array}{l}\text { mRNA- } \\
\text { AR }\end{array}$ \\
\hline Age & $\begin{array}{l}\mathrm{R} \\
P \text {-value } \\
\mathrm{N}\end{array}$ & $\begin{array}{l}0.210 \\
0.232 \\
34\end{array}$ & $\begin{array}{l}-0.196 \\
0.268 \\
34\end{array}$ & $\begin{array}{l}-0.217 \\
0.218 \\
34\end{array}$ & $\begin{array}{l}-0.037 \\
0.837 \\
34\end{array}$ & $\begin{array}{l}0.456 * * \\
0.007 \\
34\end{array}$ & $\begin{array}{l}0.123 \\
0.516 \\
30\end{array}$ & $\begin{array}{l}0.402^{*} \\
0.014 \\
37\end{array}$ & $\begin{array}{l}0.366^{*} \\
0.039 \\
32\end{array}$ & $\begin{array}{l}-0.119 \\
0.525 \\
31\end{array}$ \\
\hline $\begin{array}{l}\text { Plasma } \\
\text { TEST }\end{array}$ & $\begin{array}{l}\mathrm{R} \\
P \text {-value } \\
\mathrm{N}\end{array}$ & & $\begin{array}{l}-0.296 \\
0.170 \\
34\end{array}$ & $\begin{array}{l}-0.014 \\
0.950 \\
34\end{array}$ & $\begin{array}{l}0.396 \\
0.061 \\
34\end{array}$ & $\begin{array}{l}0.693 \\
0.000 \\
34\end{array}$ & $\begin{array}{l}-0.345 \\
0.107 \\
29\end{array}$ & $\begin{array}{l}0.021 \\
0.924 \\
34\end{array}$ & $\begin{array}{l}0.107 \\
0.625 \\
29\end{array}$ & $\begin{array}{l}0.194 \\
0.376 \\
28\end{array}$ \\
\hline $\begin{array}{l}\text { Plasma } \\
\text { AND }\end{array}$ & $\begin{array}{l}\mathrm{R} \\
P \text {-value } \\
\mathrm{N}\end{array}$ & & & $\begin{array}{l}0.582 * * \\
0.004 \\
34\end{array}$ & $\begin{array}{l}0.114 \\
0.605 \\
34\end{array}$ & $\begin{array}{l}-0.306 \\
0.155 \\
34\end{array}$ & $\begin{array}{l}0.163 \\
0.459 \\
29\end{array}$ & $\begin{array}{l}-0.158 \\
0.471 \\
34\end{array}$ & $\begin{array}{l}0.213 \\
0.330 \\
29\end{array}$ & $\begin{array}{l}-0.199 \\
0.364 \\
28\end{array}$ \\
\hline $\begin{array}{l}\text { Plasma } \\
\text { DHS }\end{array}$ & $\begin{array}{l}\mathrm{R} \\
P \text {-value } \\
\mathrm{N}\end{array}$ & & & & $\begin{array}{l}0.046 \\
0.835 \\
34\end{array}$ & $\begin{array}{l}-0.204 \\
0.351 \\
34\end{array}$ & $\begin{array}{l}0.021 \\
0.925 \\
29\end{array}$ & $\begin{array}{l}-0.366 \\
0.086 \\
34\end{array}$ & $\begin{array}{l}-0.235 \\
0.281 \\
29\end{array}$ & $\begin{array}{l}-0.149 \\
0.498 \\
28\end{array}$ \\
\hline $\begin{array}{l}\text { Plasma } \\
\text { F-TES }\end{array}$ & $\begin{array}{l}\mathrm{R} \\
P \text {-value } \\
\mathrm{N}\end{array}$ & & & & & $\begin{array}{l}-0.148 \\
0.499 \\
34\end{array}$ & $\begin{array}{l}-0.363 \\
0.088 \\
29\end{array}$ & $\begin{array}{l}-0.021 \\
0.924 \\
34\end{array}$ & $\begin{array}{l}-0.046 \\
0.834 \\
29\end{array}$ & $\begin{array}{l}-0.301 \\
0.163 \\
28\end{array}$ \\
\hline $\begin{array}{l}\text { Plasma } \\
\text { SHBG }\end{array}$ & $\begin{array}{l}\mathrm{R} \\
P \text {-value } \\
\mathrm{N}\end{array}$ & & & & & & $\begin{array}{l}-0.020 \\
0.928 \\
29\end{array}$ & $\begin{array}{l}0.224 \\
0.305 \\
34\end{array}$ & $\begin{array}{l}0.433^{*} \\
0.039 \\
29\end{array}$ & $\begin{array}{l}0.452 * \\
0.030 \\
28\end{array}$ \\
\hline Diameter & $\begin{array}{l}\mathrm{R} \\
P \text {-value } \\
\mathrm{N}\end{array}$ & & & & & & & $\begin{array}{l}-0.115 \\
0.602 \\
30\end{array}$ & $\begin{array}{l}0.146 \\
0.505 \\
25\end{array}$ & $\begin{array}{l}0.692^{* * * *} \\
0.000 \\
26\end{array}$ \\
\hline LOY\% & $\begin{array}{l}\mathrm{R} \\
P \text {-value } \\
\mathrm{N}\end{array}$ & & & & & & & & $\begin{array}{l}0.709 * * * \\
0.000 \\
32\end{array}$ & $\begin{array}{l}0.268 \\
0.216 \\
31\end{array}$ \\
\hline $\begin{array}{l}\text { mRNA- } \\
\text { SRY }\end{array}$ & $\begin{array}{l}\mathrm{R} \\
\mathrm{P} \text {-value } \\
\mathrm{N}\end{array}$ & & & & & & & & & $\begin{array}{l}0.346 \\
0.106 \\
30\end{array}$ \\
\hline
\end{tabular}

Note: The correlations between plasma TES, AND, SHBG, DHS, F-TES, diameter, LOY\% and mRNA of SRY were analyzed through partial correlation analysis accounting for age. $* P<0.05 ; * * P<0.01 ; * * * P<0.001$.

Abbreviations: AAA, abdominal aortic aneurysm; AR, androgen receptor; LOY, $Y$ chromosome loss; SRY, sex-determining region of the $Y$ chromosome; TES, testosterone; TEST, total testosterone; AND, androstenedione; SHBG, sex hormone-binding globulin; DHS, dehydroepiandrosterone; F-TES, free testosterone; R, Spearman rank correlation coefficient; $\mathrm{N}$, number. 
Table 4 Overview of the LOY ratio and classification of semiquantitative IHC analysis in AAA tissue $(n=17)$

\begin{tabular}{|c|c|c|c|c|c|c|c|}
\hline No. & AAAs & LOY ratio & LOY tissue & HE & CD3+ & IHC-AR & IHC-AR* \\
\hline I & AAA6 & $9.6 \%$ & $48 / 500$ & + & $+/++$ & $+/++$ & 1.5 \\
\hline 2 & AAA8 & $5.4 \%$ & $27 / 500$ & $+/++$ & +++ & $++/+++$ & 2.5 \\
\hline 3 & AAAI 4 & $3.4 \%$ & $17 / 500$ & + & + & \pm & 0.5 \\
\hline 4 & AAAI5 & $7.2 \%$ & $36 / 500$ & + & $++/+++$ & $+/++$ & 1.5 \\
\hline 5 & AAA20 & $6.8 \%$ & $34 / 500$ & +++ & +++ & +++ & 3 \\
\hline 6 & AAA3I & $8.6 \%$ & $43 / 500$ & $+/++$ & ++++ & $+/++$ & 1.5 \\
\hline 7 & AAA32 & $9.4 \%$ & $47 / 500$ & \pm & + & $++/+++$ & 2.5 \\
\hline 8 & AAA36 & $5.8 \%$ & $29 / 500$ & + & + & ++ & 2 \\
\hline 9 & AAA37 & $9.4 \%$ & $47 / 500$ & + & ++ & ++ & 2 \\
\hline 10 & AAA38 & $5.6 \%$ & $28 / 500$ & $+/++$ & + & \pm & 0.5 \\
\hline II & AAA47 & $9.4 \%$ & $47 / 500$ & + & $++/+++$ & $+/++$ & 1.5 \\
\hline 12 & AAA49 & $7.6 \%$ & $38 / 500$ & +++ & \pm & $+/++$ & 1.5 \\
\hline 13 & AAA52 & $7.8 \%$ & $39 / 500$ & + & $+/++$ & + & 1 \\
\hline 14 & AAA57 & $12.6 \%$ & $64 / 500$ & + & $+/++$ & $+(+/++)$ & I \\
\hline 15 & AAA60 & $10.8 \%$ & $54 / 500$ & ++ & \pm & \pm & 0.5 \\
\hline 16 & AAA68 & $6.4 \%$ & $32 / 500$ & $+/++$ & $++/+++$ & $++/+++$ & 2.5 \\
\hline 17 & AAA72 & $11.6 \%$ & $53 / 500$ & +++ & ++ & $++/+++$ & 2.5 \\
\hline
\end{tabular}

Note: No staining (-), weak positive staining $( \pm)$, scattered positive staining $(+)$, majority positive staining $(++)$, and strong overall positive staining $(+++)$. These score analyses were performed for all cells within the vessel wall and for all specimens. In addition, for interrelated quality evaluation between the abovementioned quality evaluation following scoring was used: $+/++$ and $++/+++$. *Semiquantitative analysis.

Abbreviations: AAA, abdominal aortic aneurysm; IHC, immunohistochemistry; AR, androgen receptor; LOY, Y chromosome loss.

in Y-loss susceptibility with aging may be involved. ${ }^{6,22}$ Y chromosome loss has been associated with phenotype in several malignant diseases and has been suggested as a marker predicting response to therapy. ${ }^{24-27}$ The intrinsic pathophysiologic mechanism is largely unclear. However, loss of one $\mathrm{X}$ chromosome could potentially lead to haploinsufficiency of X-linked loci, escaping X chromosome inactivation processes, ${ }^{21,28}$ and $\mathrm{Y}$ chromosome loss may similarly result in an imbalance of alleles shared with the $\mathrm{X}$ chromosome.

The Y chromosome mainly harbors genes involved in male sexual development and spermatogenesis. ${ }^{16}$ However, a number of $\mathrm{X}$ chromosome homologs potentially relevant to immune function have recently been identified in pseudoautosomal regions, including the IL-9 receptor (IL-9R) and IL-3 receptor subunit alpha (IL-3RA, CD123) (www.genecards.org). IL-9R is expressed by a series of $\mathrm{T}$ lymphocytes, including $\mathrm{Th} 2$ cells, Th17, and T-regs, ${ }^{29}$ and imbalances in this gene might thus affect the suppressive potential of the T-cell compartment. We previously identified deficient Treg function in patients with AAAs, ${ }^{30}$ which could partly be explained by the present findings. Moreover, the IL-9R gene has also been suggested to be associated with the development of some autoimmune conditions such as asthma. ${ }^{31}$ IL-3RA is an important marker during maturation of myeloid dendritic cells, which have recently been shown to play an important role in maintaining autoimmune tolerance. ${ }^{32}$ However, the influence of loss of this gene to on immunoregulation remains to be determined.

The SRY locus is an evolutionarily conserved locus on the mammalian Y chromosome responsible for testis determination and development. ${ }^{33}$ SRY encodes a transcription factor that acts by binding to and activating the testisspecific enhancer of the related gene SOX9. ${ }^{34}$ SOX9 is tightly associated with Sertoli cell development. ${ }^{35-37}$ It is also expressed in postnatal testicular Leydig cells, targeting the proteins involved in steroidogenesis, ${ }^{38}$ and has been considered to regulate testosterone production. ${ }^{39}$ We found that $S R Y$ expression was significantly decreased as a result of $\mathrm{Y}$ chromosome loss in T lymphocytes of AAA patients compared with control groups, which may contribute to the lower total and free testosterone levels in men with AAA identified in the current and previous studies. ${ }^{17}$

Lower free or total testosterone levels have been associated with higher overall and cardiovascular mortalities in middle-aged and older men. It has previously been linked with atherosclerotic plaque formation. One possible mechanism may be that testosterone depletion may predispose to AAA through loss of the beneficial effects of testosterone on endothelial function, and adverse influences on circulating lipids and vascular inflammation. ${ }^{17,40-42}$ Emerging 

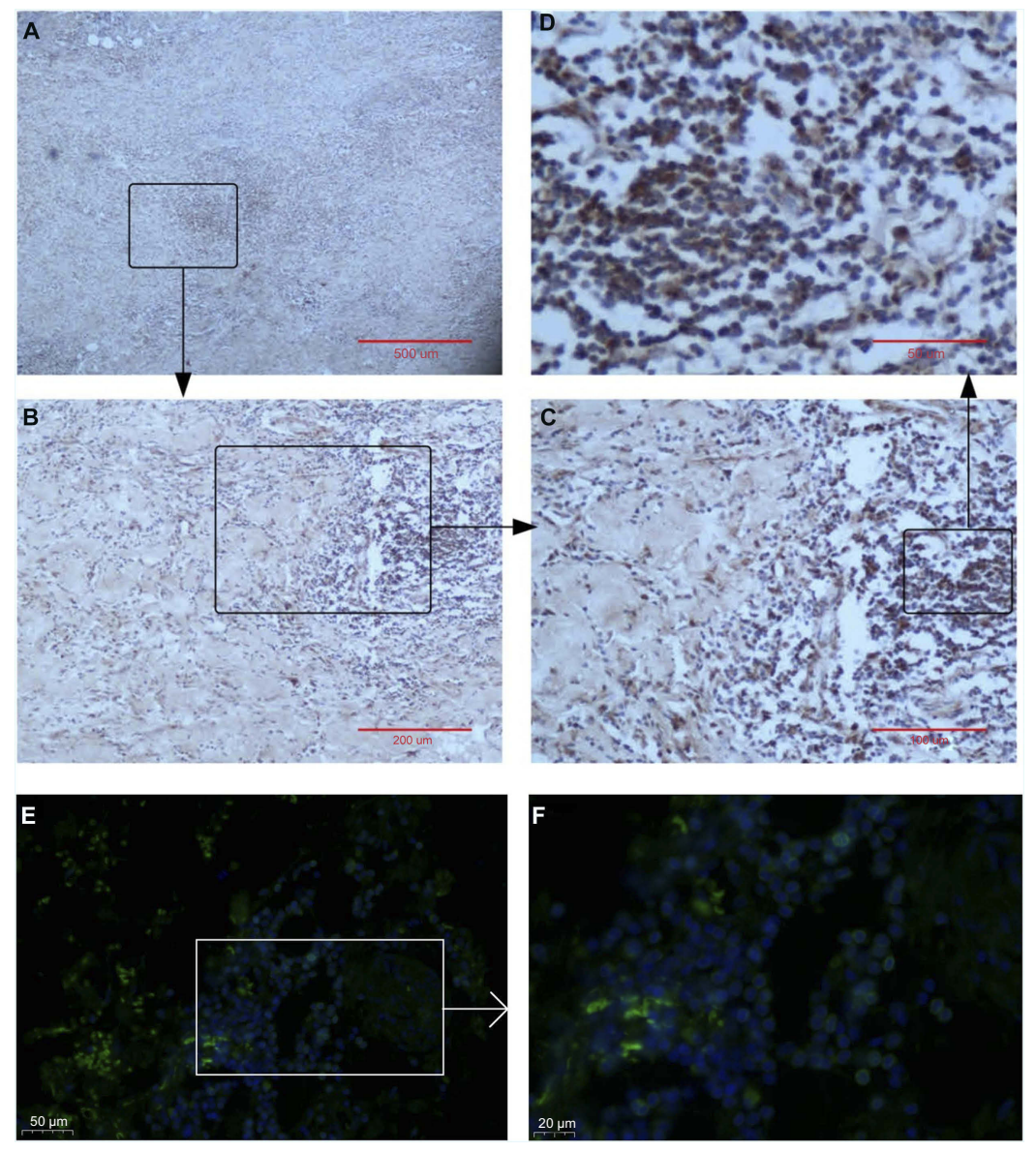

Figure 5 Selected AAA example of IHC for cellular localization and expression of AR. (A) Overview of secreted AAA tissue, scale bar represents 500 $\mu$ m; (B) AR seems to be expressed mainly in inflammatory cells and macrophages, scale bar represents $200 \mu \mathrm{m}$; (C and D) AR expression, scale bar represents $100 \mu \mathrm{m}$ and $50 \mu \mathrm{m}$, respectively. Selected AAA example of IF for cellular localization and expression of AR. ( $E$ and $\mathbf{F}$ ) AR expression, scale bar represents $50 \mu \mathrm{m}$ and $20 \mu \mathrm{m}$, respectively.

Abbreviations: AAA, abdominal aortic aneurysm; AR, androgen receptor; IHC, immunohistochemistry; IF, immunofluorescence.

evidence $^{43}$ suggests that testosterone protects against the development of autoimmune conditions such as arthritis and lung disease in male SKG mice, and removal of testosterone increased both lung and joint diseases in male mice. This mechanism may involve the ability of testosterone to modulate the development of antibodies against citrullinated proteins. Occurrence of AAA in female patients is probably involved in a different pathway in which androgen does not take a major role. Accumulating data indicate the protective effect of estrogen in the mechanism of vascular disease including aneurysms. ${ }^{44,45}$ However, it would be expected that after aging this effect has been largely weakened due to a lower level of female hormone. This may explain the increased occurrence of AAA in aged women.

Our observations establish that, in addition to the immune effects of $\mathrm{Y}$ chromosome loss, which may contribute autoimmune injury in AAA, lower $S R Y$ expression may downregulate testosterone production, thus weakening its protective role and further contributing to the formation and development of AAA.

There are limitations to this study such as the limited sample size, lack of healthy aorta tissue, and lack of vivo experiment. First, our study comprises a relatively small sample size. As in all studies, especially those with a small sample size, both beta errors (due to small cohorts) and alpha errors (due to multiplicity of comparisons) should be considered. Second, the present study illustrates a correlation between the $\mathrm{Y}$ chromosome loss and agerelated AAA; temporal relations between LOY and the age within AAA cannot be discerned. Still, as it is the first of its kind in humans, the data do provide important information. The lack of appropriate aortic wall tissue from controls limited the protein expression analysis. Third, this research mainly exploded the difference between AAA, AOD, and HC in LOY. Therefore, the residual blood samples could not be obtained abundantly from these 
AAA patients or control group, which is insufficient to perform the expression of SRY and AR at mRNA level or protein level after the FISH study. Additional studies are also needed to clarify the relationship between exogenous androgen treatment and the dilation of aortic aneurysm. Even with these potential limitations, our study results are good, providing a new clue for the mechanisms of AAA.

\section{Conclusion}

In conclusion, this study demonstrated a significant increase of $\mathrm{Y}$ chromosome loss in peripheral $\mathrm{T}$ lymphocytes and aneurysm sac wall tissue in male patients with AAAs, accompanied by decreased $S R Y$ expression in peripheral $\mathrm{T}$ lymphocytes and lower F-TES. Y chromosome loss ratio and expression of $S R Y$ mRNA level increased with age in AAA peripheral $\mathrm{T}$ lymphocytes. Furthermore, in AAA tissue, the rate of LOY increased with age and also positively associated with LOY in peripheral blood $\mathrm{T}$ lymphocytes. These findings indicate a novel clue in AAA mechanisms, and possibly a novel target for personalized treatment of this disease.

\section{Acknowledgments}

This work was supported by National Nature Science Foundation of China (Grant No. 304717076 and 81600370), Nature Science Foundation of Liaoning Province, China (Grant No. 2014021028), and Basic research program of Liaoning provincial institutions of 550 higher learning 2017 (LZDK201701), and China Postdoctoral Science Foundation (Grant No. 2018M640270).

\section{Disclosure}

The authors report no conflicts of interest in this work.

\section{References}

1. Sampson UK, Norman PE, Fowkes FG, et al. Estimation of global and regional incidence and prevalence of abdominal aortic aneurysms 1990 to 2010. Glob Heart. 2014;9(1):159-170. doi:10.1016/j.gheart.2013. 12.009

2. Barba A, Vega De Ceniga M, Estallo L, de la Fuente N, Viviens B, Izagirre M. Prevalence of abdominal aortic aneurysm is still high in certain areas of southern Europe. Ann Vasc Surg. 2013;27 (8):1068-1073. doi:10.1016/j.avsg.2013.01.017

3. Song JQ, Zhang J, Yin MD, et al. Clinico-epidemiological features of infrarenal abdominal aortic aneurysm and relevant prognostic factors. Nat Med J China. 2008;88(23):1613-1617.

4. Shimizu K, Mitchell RN, Libby P. Inflammation and cellular immune responses in abdominal aortic aneurysms. Arterioscler Thromb Vasc Biol. 2006;26(5):987-994. doi:10.1161/01.ATV.0000214999.12921.4f

5. Kuivaniemi H, Platsoucas CD, Tilson MD 3rd. Aorticaneurysms: an immune disease with a strong genetic component. Circulation. 2008;117(2):242-252. doi:10.1161/CIRCULATIONAHA.107.690982 
6. Lu S, White JV, Lin WL, et al. Aneurysmal lesions of patients with abdominal aortic aneurysm contain clonally expanded $\mathrm{T}$ cells. J Autoimmun. 2014;192(10):4897-4912.

7. Hannawa KK, Eliason JL, Upchurch GR Jr. Gender differences in abdominal aortic aneurysms. Vascular. 2009;17(Suppl 1):S30-S90.

8. Sakalihasan N, Defraigne JO, Kerstenne MA, et al. Family members of patients with abdominal aortic aneurysms are at increased risk for aneurysms: analysis of 618 probands and their families from the Liege AAA Family Study. Ann Vasc Surg. 2014;28(4):787-797.

9. Hinterseher I, Tromp G, Kuivaniemi H. Genes and abdominal aortic aneurysm. Ann Vasc Surg. 2011;25(3):388-412.

10. Libert C, Dejager L, Pinheiro I. The $\mathrm{X}$ chromosome in immune functions: when a chromosome makes the difference. Nat Rev Immunol. 2010;10(8):594-604. doi:10.1038/nri2815

11. Invernizzi P, Miozzo M, Battezzati PM, et al. Frequency of monosomy X in women with primary biliary cirrhosis. Lancet. 2004;363 (9408):533-535. doi:10.1016/S0140-6736(04)15541-4

12. Miozzo M, Selmi C, Gentilin B, et al. Preferential X chromosome loss but random inactivation characterize primary biliary cirrhosis. Hepatology. 2007;46(2):456-462. doi:10.1002/hep.21696

13. Jeong SY, Park SJ, Lee SJ, Park HJ, Kim HJ. Loss of Y chromosome in the malignant peripheral nerve sheet tumor of a patient with neurofibromatosis type 1. J Korean Med Sci. 2010;25(5):804-808. doi:10.3346/jkms.2010.25.5.804

14. Park SJ, Jeong SY, Kim HJ. Y chromosome loss and other genomic alterations in hepatocellular carcinoma cell lines analyzed by $\mathrm{CGH}$ and CGH array. Cancer Genet Cytogenet. 2006;166(1):56-64. doi:10.1016/j.cancergencyto.2005.08.022

15. Lleo A, Oertelt-Prigione S, Bianchi I, et al. Y chromosome loss in male patients with primary biliary cirrhosis. $J$ Autoimmun. 2013;41:87-91. doi:10.1016/j.jaut.2012.12.008

16. Kido T, Lau YF. Roles of the Y chromosome genes in human cancers. Asian J Androl. 2015;17(3):373-380. doi:10.4103/1008-682X.150842

17. Yeap BB, Hyde Z, Norman PE, Chubb SA, Golledge J. Associations of total testosterone, sex hormone-binding globulin, calculated free testosterone, and luteinizing hormone with prevalence of abdominal aortic aneurysm in older men. J Clin Endocrinol Meta B. 2010;95 (3):1123-1130. doi:10.1210/jc.2009-1696

18. Henriques T, Zhang X, Yiannikouris FB, Daugherty A, Cassis LA Androgen increases AT1a receptor expression in abdominal aortas to promote angiotensin II-induced AAAs in apolipoprotein E-deficient mice. Arterioscler Thromb Vasc Biol. 2008;28(7):1251-1256. doi:10.1161/ATVBAHA.107.160382

19. Klink A, Hyafil F, Rudd J, et al. Diagnostic and therapeutic strategies for small abdominal aortic aneurysms. Nat Rev Cardiol. 2011;8 (6):338-347. doi:10.1038/nrcardio.2011.1

20. Dumanski JP, Rasi C, Lönn M, et al. Mutagenesis. Smoking is associated with mosaic loss of chromosome Y. Science. 2015;347 (6217):81-83. doi:10.1126/science.1262092

21. Invernizzi P, Pasini S, Selmi C, Gershwin ME, Podda M. Female predominance and $\mathrm{X}$ chromosome defects in autoimmune diseases. J Autoimmun. 2009;33(1):12-16. doi:10.1016/j.jaut.2009.03.005

22. Persani L, Bonomi M, Lleo A, et al. Increased loss of the $\mathrm{Y}$ chromosome in peripheral blood cells in male patients with autoimmune thyroiditis. $J$ Autoimmun. 2012;38(2-3):J193-J196. doi:10.1016/j.jaut.2011.11.011

23. Guttenbach M, Koschorz B, Bernthaler U, Grimm T, Schmid M. Sex chromosome loss and aging: in situ hybridization studies on human interphase nuclei. Am J Hum Genet. 1995;57(5):1143-1150.

24. Wong AK, Fang B, Zhang L, Guo X, Lee S, Schreck R. Loss of the $\mathrm{Y}$ chromosome: an age-related or clonal phenomenon in acute myelogenous leukemia/myelodysplastic syndrome? Arch Pathol Lab Med. 2008;132(8):1329-1332. doi:10.1043/1543-2165(2008)132 [1329:LOTYCA]2.0.CO;2
25. Minner S, Kilgue A, Stahl P, et al. Y chromosome loss is a frequent early event in urothelial bladder cancer. Pathology. 2010;42 (4):356-359. doi:10.3109/00313021003767298

26. Forsberg LA, Rasi C, Malmqvist N, et al. Mosaic loss of chromosome $\mathrm{Y}$ in peripheral blood is associated with shorter survival and higher risk of cancer. Nat Genet. 2014;46(6):624-628. doi:10.1038/ ng.2966

27. Kujawski M, Jarmuz M, Rydzanicz M, et al. Frequent chromosome $\mathrm{Y}$ loss in primary, second primary and metastatic squamous cell carcinomas of the head and neck region. Cancer Lett. 2004;208 (1):95-101. doi:10.1016/j.canlet.2003.11.006

28. Invernizzi P, Pasini S, Selmi C, Miozzo M, Podda M. Skewing of $\mathrm{X}$ chromosome inactivation in autoimmunity. Autoimmunity. 2008;41 (4):272-277. doi:10.1080/08916930802024574

29. Noelle RJ, Nowak EC. Cellular sources and immune functions of interleukin-9.Nat. Rev Immunol. 2010;10(10):683-687. doi:10.1038/ nri2848

30. Yin M, Zhang J, Wang Y, et al. Deficient CD4+CD25+ T regulatory cell function in patients with abdominal aortic aneurysms. Arterioscler Thromb Vasc Biol. 2010;30(9):1825-1831. doi:10.1161/ ATVBAHA.109.200303

31. Shimbara A, Christodoulopoulos P, Soussi-Gounni A, et al. IL-9 and its receptor in allergic and nonallergic lung disease: increased expression in asthma. J Allergy Clin Immunol. 2000;105(1 pt 1):108-115. doi:10.1016/S0091-6749(00)90185-4

32. TestaU S, Pelosi E, Frankel A. CD 123 is a membrane biomarker and a therapeutic target in hematologic malignancies. Biomark Res. 2014;2(1):4. doi:10.1186/2050-7771-2-4

33. Larney C, Bailey TL, Koopman P. Switching on sex: transcriptional regulation of the testis-determining gene Sry. Development. 2014;141 (11):2195-2205. doi:10.1242/dev.107052

34. Sekido R, Lovell-Badge R. Sex determination involves synergistic action of SRY and SF1 on a specific Sox9 enhancer. Nature. 2008;453(7197):930-934. doi:10.1038/nature06944

35. Kent J, Wheatley SC, Andrews JE, Sinclair AH, Koopman P. A male-specific role for SOX9 in vertebrate sex determination. Development. 1996;122(9):2813-2822.

36. Morais Da Silva S, Hacker A, Harley V, Goodfellow P, Swain A, Lovell-Badge R. Sox9 expression during gonadal development implies a conserved role for the gene in testis differentiation in mammals and birds. Nat Genet. 1996;14(1):62-68. doi:10.1038/ ng0996-62

37. Vidal VP, Chaboissier MC, De Rooij DG, Schedl A. Sox9 induces testis development in XX transgenic mice. Nat Genet. 2001;28 (3):216-217. doi:10.1038/90046

38. Bhandari RK, Haque MM, Skinner MK. Global genome analysis of the downstream binding targets of testis determining factor SRY and SOX9. PLoS One. 2012;7(9):e43380. doi:10.1371/journal. pone. 0043380

39. Daigle M, Roumaud P, Martin LJ. Expressions of Sox9, Sox5, and Sox13 transcription factors in mice testis during postnatal development. Mol Cell Biochem. 2015;407(1-2):209-221. doi:10.1007/s11010-015-2470-7

40. F C W, Von Eckardstein A. Androgens and coronary artery disease. Endocr Rev. 2003;24(2):183-217. doi:10.1210/er.2001-0025

41. Tivesten A, Mellstrom D, Jutberger H, et al. Low serum testosterone and high serum estradiol associate with lower extremity peripheral arterial disease in elderly men. The MrOS study in Sweden. J Am Coll Cardiol. 2007;50(11):1070-1076. doi:10.1016/j.jacc.2007.04.088

42. Norata GD, Tibolla G, Seccomandi PM, Poletti A, Catapano AL. Dihydrotestosterone decreases tumor necrosis factor-alpha and lipopolysaccharide-induced inflammatory response in human endothelial cells. J Clin Endocrinol Metab. 2006;91(2):546-554. doi:10.1210/jc.2005-1664 
43. Keith RC, Sokolove J, Edelman BL, et al. Testosterone is protective in thesexually dimorphic development of arthritis and lung disease in SKG mice. Arthritis. 2013;65(6):1487-1493. doi:10.1002/art.37943

44. Wu XF, Zhang J, Paskauskas S, Xin SJ, Duan ZQ. The role of estrogen in the formation ofexperimental abdominal aortic aneurysm. Am J Surg. 2009;197(1):49-54. doi:10.1016/j.amjsurg.2007.11.022
45. Sinha I, Cho BS, Roelofs KJ, Stanley JC, Henke PK, Upchurch GR Jr. Female gender attenuatescytokine and chemokine expression and leukocyte recruitment in experimental rodent abdominal aortic aneurysms. Ann N Y AcadSci. 2006;1085:367-379. doi:10.1196/ annals. 1383.027 


\section{Supplementary material}

Table SI The adjusted logistic regression analysis of peripheral T lymphocytes LOY ratio and association with AAA clinical comorbidity

\begin{tabular}{|l|l|l|l|l|l|l|}
\hline \multirow{2}{*}{} & \multicolumn{2}{l}{ Model I } & \multicolumn{2}{l|}{ Model 2 } \\
\cline { 2 - 7 } & $\boldsymbol{\beta}$ & OR (95\% CI) & $\boldsymbol{p}$-Value & $\boldsymbol{\beta}$ & \multicolumn{2}{l|}{ OR (95\% CI) } \\
\hline Hypertension & 0.082 & $1.086(0.910-1.294)$ & 0.36 & 0.054 & $1.056(0.865-1.289)$ & 0.592 \\
Diabetes mellitus & -0.235 & $0.791(0.552-1.133)$ & 0.201 & -0.232 & $0.793(0.533-1.178)$ & 0.251 \\
Coronary artery disease & 0.265 & $1.304(0.985-1.726)$ & 0.063 & 0.143 & $1.153(0.831-1.600)$ & 0.393 \\
Smoking & 0.064 & $1.067(0.893-1.273)$ & 0.476 & 0.12 & $1.127(0.921-1.380)$ & 0.246 \\
\hline
\end{tabular}

Note: Model I: no adjustments; Model 2: adjusted for age.

Abbreviations: $\beta$, regression coefficient; AAA, abdominal aortic aneurysm; LOY, Y chromosome loss; OR, odds ratio; $95 \%$ Cl: $95 \%$ confidence interval.

Clinical Interventions in Aging

\section{Publish your work in this journal}

Clinical Interventions in Aging is an international, peer-reviewed journal focusing on evidence-based reports on the value or lack thereof of treatments intended to prevent or delay the onset of maladaptive correlates of aging in human beings. This journal is indexed on PubMed Central, MedLine, CAS, Scopus and the Elsevier
Bibliographic databases. The manuscript management system is completely online and includes a very quick and fair peer-review system, which is all easy to use. Visit http://www.dovepress.com/ testimonials.php to read real quotes from published authors. 